EXTENDED REPORT

\title{
A randomised controlled trial of occupational therapy for people with early rheumatoid arthritis
}

\author{
A Hammond, A Young, R Kidao
}

Ann Rheum Dis 2004;63:23-30. doi: 10.1136/ard.2002.001511

See end of article for authors' affiliations

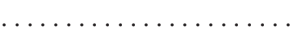

Correspondence to: Dr A Hammond, Rheumatology, Derbyshire Royal Infirmary, London Road, Derby DE1 2QY, UK; Alison.Hammond @sdah-tr.trent.nhs.uk

Accepted 28 April 2003
Background: Occupational therapy (OT) aims at improving performance of daily living tasks, facilitating successful adjustments in lifestyle, and preventing losses of function.

Objective: To evaluate the effects of a pragmatic, comprehensive OT programme on self management and health status of people with early rheumatoid arthritis (RA) ( $<2.5$ years).

Methods: A randomised, controlled "assessor blinded" trial was conducted with assessments made at entry, 6, 12, and 24 months. Main outcomes were AIMS2: physical function (PF), pain visual analogue scale (VAS), and Arthritis Self-Efficacy Scale (ASES).

Results: Groups had similar disease duration (9 months OT $(n=162)$ v 10 months control $(n=164))$. The OT group received 7.57 (SD 3.04) hours of therapy. Self management significantly increased in the OT group. Otherwise, there were no significant differences in any outcome measures, or between groups, by ACR functional class: AIMS2: PF $(F=0.04 ; p=0.96)$; pain VAS $(F=0.29 ; p=0.74)$; total ASES score $(F=0.93 ; p=0.39)$.

Conclusions: OT improved self management but not health status in early RA. Functional ability remains reasonably good for many in the first five years, so preventive benefits of self management may not yet be apparent and longer follow up is needed. Although many considered the education and therapy useful, insufficient numbers in the OT group used self management sufficiently to make a difference. Behavioural approaches can improve adherence and, potentially, the long term benefits. Future research should evaluate OT as a complex intervention and develop programmes from a theoretical and evidence base.

$\mathrm{T}$ he development of early, aggressive treatment in rheumatoid arthritis (RA) has led to occupational therapy (OT), physiotherapy, and patient education interventions also being provided earlier. By providing disease information, facilitating a positive attitude towards being a self manager, and teaching effective strategies for self management, people with RA may be empowered to take a "preventive" approach to help maintain or improve health, minimise dysfunction, and promote optimum participation in normal activities. ${ }^{1}$

OT includes both therapeutic and educational interventions and aims at improving performance of daily living tasks, facilitating successful adjustments in lifestyle, and preventing losses of function. ${ }^{2}$ Therapists also aim at improving psychological adjustment to living with arthritis by enabling people to have a greater sense of control of their symptoms through using self management methods and improving self efficacy. OT emphasises maintaining hand function and, as hand involvement occurs early in the disease, the occupational therapist is often the first or only therapist that patients visit. ${ }^{1}$ Treatment includes assessment of functional (personal and domestic activities of daily living (ADL), work and leisure), physical, psychological, and social abilities and the person's understanding of their disease. Individualised treatment programmes are developed including arthritis education (individual and group), ADL training, joint protection, fatigue management and exercise (particularly for the hand and arm), splinting (wrist/hand, feet, and neck as appropriate), assistive devices, work and leisure counselling, sexual advice, relaxation, and pain and stress management training as necessary. Interventions emphasise achieving empathetic rapport and providing counselling and support appropriate to the person's needs to explore the impact of RA on their lives and assist in adjusting lifestyle.

This approach has been shown to be effective with people with established RA. Helewa et al conducted a crossover trial with 105 people with RA, aged 18-70 years, disease duration of 8-10 years, with moderate to severe RA. ${ }^{3}$ A comprehensive OT programme was provided and significant improvements in ADL and mobility were reported. The authors considered the six week follow up probably too short to detect changes in other measures such as pain, depression, and social function. There have been no other randomised controlled trials of comprehensive OT in RA. Specific OT interventions have also been shown to be effective in people with longer disease duration. Hand exercises can increase grip and maintain range of movement in people with moderate RA 6-10 years after diagnosis..$^{4-7}$ Wrist working splints reduce pain during activity in those with moderate RA 3-8 years after diagnosis. ${ }^{8-10}$ Joint protection, in the short term, reduces pain, tender joint counts, and improves functional ability in women with mild-moderate RA (average eight years' duration $\left.^{11-13}\right)$. Few OT studies have reported results specific to people with early RA. Joint protection education has been shown to be effective in reducing pain, early morning stiffness, and numbers of disease flare ups, and increasing grip strength in those with mild to moderate RA on average 18 months after diagnosis (range 0-5 years) and with hand function problems. ${ }^{14}$ A recent systematic review has concluded that there is limited but encouraging evidence that OT

Abbreviations: ACR, American College of Rheumatology; ADL activities of daily living; AEP, arthritis education programme; AIMS Arthritis Impact Measurement Scale; ANOVA, analysis of variance; ASES, Arthritis Self-Efficacy Scale; DMARD, disease modifying antirheumatic drug; $H A Q$, Health Assessment Questionnaire; OT, occupational therapy; PF, physical function; RA, rheumatoid arthritis; VAS, visual analogue scale 
has a positive effect on functional ability and pain in people with RA. ${ }^{15}$

Based on limited evidence from the effectiveness of OT in later stage RA, there has been a major service shift to provide OT and patient education early in order to help people adopt a preventive approach and adjust their lifestyle successfully. However, there have been no randomised controlled trials of OT in early RA to evaluate whether this secondary preventive approach is effective. This study aimed at evaluating a comprehensive OT programme on the effect of self management on functional, disease, physical, and psychosocial status of people with early RA.

\section{PATIENTS AND METHODS \\ Patients}

People with RA were recruited from 11 hospitals in the former North Thames Regional Health Authority. People were eligible to participate if aged over 18 years; diagnosed with RA by a consultant rheumatologist within the past 2.5 years; required active medical treatment; had had no or minimal OT previously; and could speak and read English adequately to complete assessments.

\section{Trial design}

A randomised, controlled, "assessor blinded" clinical trial was conducted. Ethical approval was obtained before the study starting at each hospital. Rheumatologists referred patients from outpatient clinics. After referral, patients were contacted with an invitation letter and information sheet. Those agreeing to participate were randomly allocated to the OT plus usual rheumatology care group or to the usual rheumatology care only control group. Normally there was no or minimal OT and physiotherapy available for people with early RA at 9/11 of the hospitals, unless they had marked functional difficulties. Most departments did not have rheumatology nurse practitioners. Computer generated random numbers were used with block allocation ${ }^{16}$ for each centre, using pre-prepared sealed envelopes, to ensure an even distribution of OT and control groups across all centres.

Assessments were conducted at participants' referring hospitals. The independent assessor, before the baseline assessment, explained the trial further, any questions were answered, and informed written consent obtained. Participants were assessed at baseline, 6, 12, and 24 months. The study was conducted between 1996 and 2002.

\section{Sample size}

Change in functional ability was selected to calculate sample size. Boers and Tugwell recommend that a $20 \%$ difference in group scores can be considered clinically meaningful. ${ }^{17}$ Using published Health Assessment Questionnaire (HAQ) data from a study of people with $<1$ year's disease duration, ${ }^{18}$ with a mean score of 1.3 (SD 0.8) (power 80\%, p =0.05), a minimum of 150 people were needed in each group.

\section{Intervention}

After baseline assessment, participants randomly allocated to OT were referred on by the trial manager. Therapists started treatment within 10 days of referral and completed this within 6-8 weeks whenever possible. Participants knew of their group allocation at this point. OT was provided over five sessions: four one-hour individual treatments (usually held weekly) and a two-hour group arthritis education programme (AEP), with extra appointments if necessary. Participants were reviewed at 6 and 12 months (one hour appointments). The intervention lasted for eight hours over one year. The programme was devised by occupational therapists at St Albans and Hemel Hempstead Hospitals, as an early secondary preventive intervention providing comprehensive information about RA and teaching self management methods, and included advice usually provided by other health professionals because of limited staffing (for example, exercise, footcare). It had been refined clinically over six years before the trial started.

Senior rheumatology occupational therapists, trained in delivering this programme, provided the intervention. Training included a five day course in rheumatology OT (optional), a manual detailing the OT programme, and observation of the programme delivered by experienced therapists from the originating hospitals. The trial therapists were observed delivering the programme and given feedback on performance, to standardise programme delivery as far as possible. One of the experienced therapists visited the trial therapists periodically to observe practice and give feedback. OT assessment forms and patient information sheets were standardised between centres.

All participants in the OT group were initially interviewed about their medical and social history and disease status. ADL, hand, posture, and walking assessments and discussion of the impact of RA on participants' lifestyle were conducted to identify their problems and priorities for therapy. This took 1.5-2 hours. An individualised treatment plan was negotiated, providing essential plus optional interventions relevant to the person. Essential interventions were information about RA, its treatment and management; relevant ADL training; joint protection and energy conservation; posture and positioning advice; and a range of movement hand exercise home programme. A supportive approach of listening and counselling was integral. The group AEP included information on RA, its effects on joints and emphasised self managing symptoms through exercise, joint protection, and energy conservation. The possible psychosocial effects of RA and coping strategies were discussed. Optional programme components to meet an individual's needs included provision/recommendation of assistive devices, referral to social services for house adaptations and large equipment, splints (resting and wrist working, thumb, finger or neck as appropriate); upper and lower limb exercises, referring to physiotherapy if needed; basic gait analysis and foot advice, referring to podiatry as necessary; advice on leisure and work; work assessment; advice on benefits, and referral to a social worker as necessary; relaxation training and coping with stress; discussing the effect of RA on relationships and mood; and sexual advice. Six- and 12-month review appointments included hand and ADL assessment, progress adopting self management behaviours and provided additional interventions as necessary.

\section{Outcome measures}

Assessments were conducted throughout by the same person, who was unaware of the group allocation. Discussion about the OT programme was avoided, as was discussion about participants with treatment staff.

\section{Biographical details}

Biographical details were recorded at the baseline assessment: age, sex, marital status, employment status, social class, formal educational level, and disease duration since diagnosis. At each assessment the following were recorded: current drug treatment, number of visits to doctors for arthritis, and treatment from other health professionals in the past six months.

\section{Functional assessment}

The HAQ was completed at 0, 12, and 24 months. ${ }^{19}$ The Arthritis Impact Measurement Scale 2 (AIMS2 ${ }^{20}$ ) was also completed at each assessment, as, unlike the HAQ, scores with AIMS2 are not worsened by the use of assistive devices. 
Occupational therapists commonly recommend the use of these to improve clients' functional ability and for joint protection. It includes 12 subscales-six of which are combined to form a physical function (PF) scale: mobility, walking and bending, hand and finger function, arm function, self care, and household abilities. AIMS2 scores range from 0 to 10 , with 0 representing good function.

\section{Disease activity}

Disease activity was evaluated by standardised procedures ${ }^{21}$ : 28 tender and swollen joint count (with each joint graded on a $0-3$ scale; $0=$ no pain/swelling to $3=$ severe); American College of Rheumatology (ACR) functional grade ${ }^{22}$; duration of early morning stiffness (minutes); $100 \mathrm{~mm}$ pain visual analogue scale (VAS) in the past week.

\section{Hand status}

Hand status was evaluated using grip strength (Jamar dynamometer) ${ }^{23}$ and hand function (Jebsen hand function test $\left.^{24}\right)$.

\section{Psychosocial status}

Psychosocial status was measured with the Arthritis SelfEfficacy Scale (ASES ${ }^{25}$ ), evaluating belief in ability to manage pain, other arthritis symptoms, and functional ability. Scores range from 0 to 100, with higher scores indicating higher self efficacy. The Rheumatoid Attitudes Index ${ }^{26}$ evaluates perceived control (internality subscale, score range 0-36) and helplessness (subscale score range 0-30) in relation to arthritis. Higher scores indicate worse learned helplessness and poorer sense of internal control. Two scales of the AIMS2 are combined to form the Affect Scale-level of tension and of mood (measures of anxiety and depression).

\section{Self reported adherence}

Adherence to hand, arm, and fitness exercise, energy conservation, and joint protection strategies were recorded using a five point scale: $\mathrm{l}=$ never; to $5=$ always/daily). Use of assistive devices and splints was similarly recorded.

\section{Duration and content of therapy programmes}

Duration and content of therapy programmes were recorded by the occupational therapists providing the intervention.

\section{Statistical analysis}

Change scores for outcome measures from baseline to 6, 12, and 24 months were calculated and compared using unpaired $t$ tests, to identify whether any significant differences between groups occurred. An intention to treat analysis was conducted, with $\mathrm{p}=0.01$ considered significant because of the large number of tests conducted. Secondary analyses were also conducted on a non-intention to treat basis, but as the same conclusions were reached the data are not shown. Categorical data were analysed by $\chi^{2}$ test and ordinal data by Mann-Whitney tests to identify group differences. Groups were stratified by ACR functional class. Exploratory analysis and repeated measures analysis of variance (ANOVA) were used to identify any differences in the primary outcome measures between groups. Differences in clinical and demographic variables at baseline between the patients who were lost to follow up during the two year period were assessed using $\chi^{2}$ or unpaired $t$ tests as appropriate.

\section{RESULTS}

\section{Recruitment and demographic data}

Over the three year recruitment period, 475 people were referred (fig 1 shows the trial summary). Table 1 gives the demographic data. The groups had similar demographic and baseline variables-except that the control group was

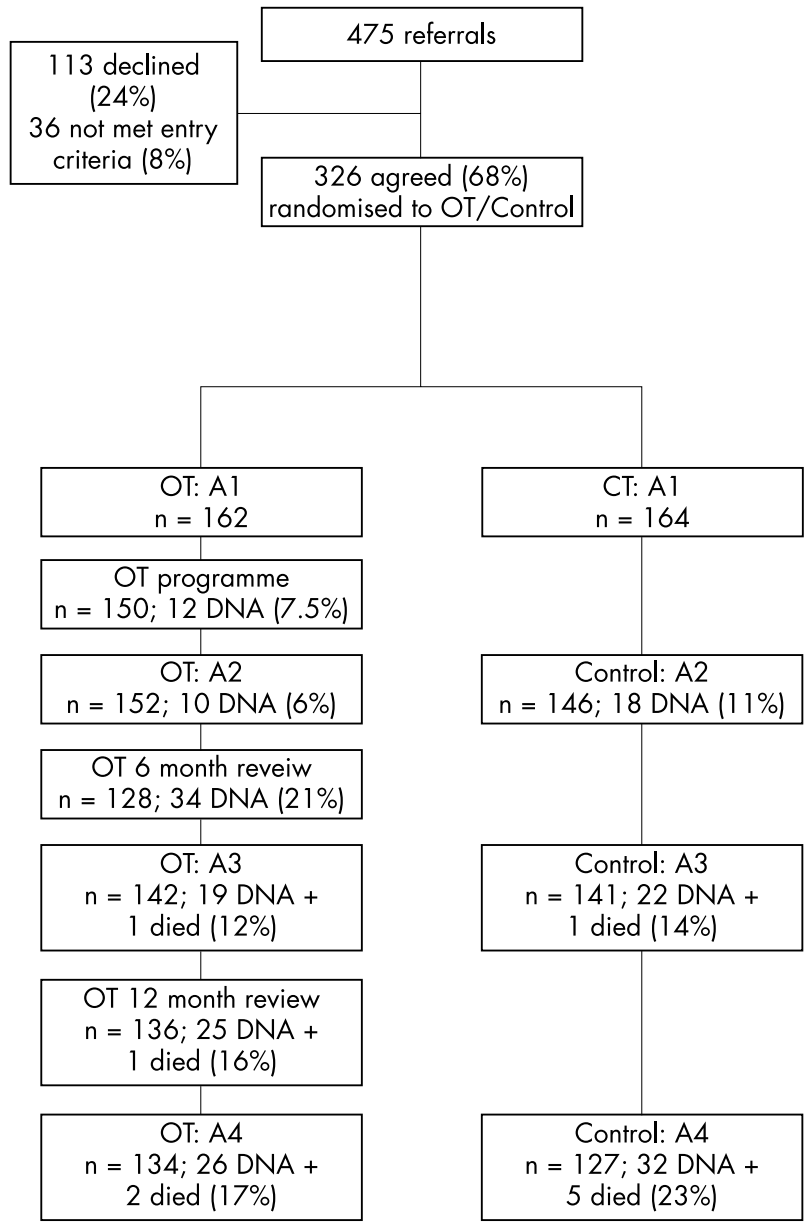

Figure 1 Consort diagram (DNA = did not attend).

significantly older by, on average, 3.2 years $(t=-2.10$; $\mathrm{p}=0.04)$. Average disease duration was 9 months with a range of 1-30 months (that is, the upper limit for entry), with 161 (49\%) up to 6 months since diagnosis. The AIMS PF score was greater than 3.33 (that is, moderate/severe functional problems) in 52/162 (32\%) of the OT and 63/164 $(38 \%)$ of the control groups. No significant differences in demographic and clinical variables at baseline were found between participants completing the trial and those lost to follow up.

At the trial start, $78 \%(\mathrm{n}=126)$ of the OT and $72 \%$ $(\mathrm{n}=118)$ of the control group were prescribed disease modifying antirheumatic drugs (DMARDs), 60\% ( $\mathrm{n}=98)$ and $53 \%(n=87)$, respectively, were prescribed non-steroidal anti-inflammatory drugs, 36\% $(\mathrm{n}=59)$ and $36 \%(\mathrm{n}=59)$, respectively, were prescribed low dose oral steroids. Ten $(6 \%)$ of the OT and $11(7 \%)$ of the control groups were not receiving any drug treatment. During the trial, there was no significant difference in the numbers taking no DMARDs ( $10 \%$ OT $v 13 \%$ control); one ( $53 \% v 53 \%$ ), two (31\% v 26\%), three $(5 \% \vee 7 \%)$, or four DMARDs $(1 \% \vee 1 \%)\left(\chi^{2}=2.16\right.$; $\mathrm{p}=0.47)$. During the two years, there was no significant difference in the numbers of people taking oral low dose steroids $(41 \%(n=67)$ of the OT and $47 \%(n=77)$ of the control groups $\left.\left(\chi^{2}=1.15 ; \mathrm{p}=0.3\right)\right)$.

\section{Occupational therapy received}

Of those in the OT group, 149/162 (93\%) attended the programme for, on average, 7.6 (SD 3.1; range 0-19) hours. The initial interview was attended by $93 \%$; essential 
Table 1 Demographic information: mean (SD)

\begin{tabular}{|c|c|c|c|}
\hline & $\begin{array}{l}\text { Occupational } \\
\text { therapy group } \\
(n=162)\end{array}$ & $\begin{array}{l}\text { Control group } \\
(n=164)\end{array}$ & $\mathbf{p}$ \\
\hline Age (years) & 53.9 (13.9) & $57.1 *(13.5)$ & 0.04 \\
\hline Disease duration (months) & $9.0(7.7)$ & $9.9(8.8)$ & 0.31 \\
\hline Sex: M/F & $41 / 121$ & $49 / 115$ & 0.39 \\
\hline \multicolumn{4}{|l|}{ Socioeconomic status } \\
\hline Professional I & 2 & 2 & \\
\hline Professional II & 17 & 15 & \\
\hline Skilled III & 45 & 39 & \\
\hline Semi-skilled IV & 43 & 58 & \\
\hline Unskilled V & 55 & 50 & 0.56 \\
\hline \multicolumn{4}{|l|}{ Ethnic group: } \\
\hline Black & 9 & 4 & \\
\hline White UK & 130 & 134 & \\
\hline White-non-UK & 5 & 9 & \\
\hline Asian & 8 & 9 & \\
\hline Chinese & 3 & 0 & \\
\hline Other & 7 & 8 & 0.19 \\
\hline \multicolumn{4}{|l|}{ Marital status: } \\
\hline Married/living with partner & 115 & 111 & \\
\hline Single & 12 & 14 & \\
\hline Divorced & 12 & 13 & \\
\hline Separated & 4 & 5 & \\
\hline Widowed & 19 & 21 & 0.43 \\
\hline \multicolumn{4}{|l|}{ Highest education level: } \\
\hline No formal qualifications & 67 & 84 & \\
\hline GCSE or equivalent & 50 & 43 & \\
\hline A level or equivalent & 8 & 8 & \\
\hline Diploma & 13 & 7 & \\
\hline University degree & 14 & 11 & \\
\hline Other & 10 & 11 & 0.48 \\
\hline \multicolumn{4}{|l|}{ Work status } \\
\hline Paid work & 65 & 64 & \\
\hline Homemaker & 27 & 21 & \\
\hline Unemployed & 9 & 7 & \\
\hline Disabled & 12 & 9 & \\
\hline Retired & 49 & 62 & 0.51 \\
\hline \multicolumn{4}{|l|}{ ACR functional class } \\
\hline 1 & 15 & 20 & \\
\hline$\|$ & 121 & 106 & \\
\hline III & 26 & 38 & \\
\hline IV & 0 & 2 & 0.15 \\
\hline
\end{tabular}

interventions by $90 \%$, and optional components as necessary-for example, assistive devices (50\%); splints (46\%). About two hours' administration for each patient was needed. The programme cost on average $£ 335$ per patient (costed at $£ 35$ an hour for senior OT time), excluding splints, assistive devices and other adaptations required.

\section{Adherence with self management and other treatments received}

The OT group reported using some self management methods significantly more frequently at 6,12 , and 24 months than the control group (table 2), particularly hand exercises, joint protection, and rest. At 24 months, significantly more of the OT group $(\mathrm{n}=88(54 \%))$ had received working splints (control group: $\mathrm{n}=53(32 \%) ; \chi^{2}=16.61 ; \mathrm{p}=0.001$ ), although comparatively they were not worn more often $\left(\chi^{2}=3.51 ; p=0.48\right)$, and over a third were not wearing these $(\mathrm{OT}=39 / 88 \quad(44 \%) ; \quad$ control $=23 / 53 \quad(43 \%))$. Significantly more of the OT group (31 (19\%)) had received resting splints (control group $\left.7(4 \%) ; \chi^{2}=17.18 ; p=0.001\right)$. The OT group owned on average 2.5 (SD 2.8) assistive devices each at two years compared with 1.4 (SD 2.1) owned by the control group $(t=3.59 ; \mathrm{p}=0.001)$, and these were used significantly more often $(t=3.1 ; \mathrm{p}=0.002)$. Less than $7 \%(\mathrm{n}=11)$ of the control group received OT during the trial. There were no significant differences between groups in the number of participants receiving physiotherapy or podiatry (table 2 ).

\section{Outcome measures}

Table 3 compares the outcomes obtained. There were no significant differences between the OT and control groups for any of the disease, physical, functional, psychosocial or hand measures, neither was there any trend approaching significance. Results were not significantly different when analysed on a non-intention to treat basis (data not shown). Within group analyses showed that both groups had significantly improved AIMS2 PF scores (OT: $\mathrm{F}=5.03 ; \mathrm{df}=3 ; \mathrm{p}=0.002$; control: $\mathrm{F}=11.02 ; \mathrm{df}=3 ; \mathrm{p}=0.001)$ and total self efficacy scores (OT: $\mathrm{F}=7.64 ; \mathrm{p}=0.001$; control: $\mathrm{F}=7.31 ; \mathrm{p}=0.001$ ), but pain VAS scores changed little (OT: $F=1.21 ; p=0.31$; control: $\mathrm{F}=0.36 ; \mathrm{p}=0.78$ ).

As OT may be more effective for those with more functional problems initially, exploratory analysis and repeated measures ANOVA were conducted to identify whether the primary outcomes for those in ACR functional classes I, II, and III at baseline differed between the groups over the two year period. There were no significant differences: AIMS2 PF $\left(\mathrm{F}_{(1,312)}=0.04 ; \mathrm{p}=0.96\right)$; pain VAS $\left(\mathrm{F}_{(1,318)}=0.29 ; \mathrm{p}=0.74\right)$; and total self efficacy scale score $\left(\mathrm{F}_{(1,316)}=0.93 ; \mathrm{p}=0.39\right)$.

\section{DISCUSSION}

This intensive programme of OT aimed to be a secondary preventive intervention, facilitating adjustments in lifestyle and preventing losses of function in the long term. It was successful in leading to greater use of self management. However, over the two year follow up period it did not make a significant difference to the health status of people with early RA. Previous research showed that OT programmes and interventions are effective at a later stage of the disease. Why was OT apparently ineffective in early RA? There may be several explanations.

Firstly, outcomes changed similarly in both groups. Benefits were probably due to drug treatment and this "erased" any benefits that might have resulted from OT. Disease activity strongly correlates with physical function in early RA, and drug management has a major role in affecting this. ${ }^{27}$ Longitudinal studies in early RA show that functional ability does not significantly decrease in the first five years. $^{28-32}$ There is considerable variability: $16 \%$ develop severe functional disability, $44 \%$ a remitting/relapsing course, and $40 \%$ do relatively well. ${ }^{32}$ Perhaps OT is more effective for those with greater functional problems initially? There were no significant differences in outcomes between ACR functional class groups, possibly because there were insufficient numbers of people with moderate to severe RA at the start of the study to detect differences. A longer term follow up (for example, at five and 10 years) would show whether this programme can truly be preventive and benefited any subset(s) of patients specifically.

Secondly, given that a third of the patients had mild disease throughout the study, some outcomes might have been insufficiently sensitive to detect benefits of OT (that is, a "floor" effect). HAQ scores are worsened by the use of assistive devices (a secondary preventive joint protection strategy), meaning that this is a less relevant outcome for OT. AIMS2 does not use this scoring method, and was therefore included. Individualised outcome measures may identify what participants consider to be important changes (for example, the Disease Repercussion Profile, ${ }^{33}$ ). Detailed physical function measures relevant to the hand and foot, which are most affected in early RA, may also be more appropriate (for example, the Disability Arm Shoulder Hand Index $\left.{ }^{34}\right)$. Stucki recommends that outcomes relevant to secondary prevention are needed (such as muscle strength, mobility, and coping strategies) as it may take years before a 
Table 2 Adherence with self management methods (percentage of participants reporting using methods very offen or three or more times a week and treatments received ( $n=$ number of valid replies)

\begin{tabular}{|c|c|c|c|c|c|c|c|c|}
\hline \multirow[b]{2}{*}{ Self management method } & \multicolumn{2}{|l|}{0 Months } & \multicolumn{2}{|l|}{6 Months } & \multicolumn{2}{|l|}{12 Months } & \multicolumn{2}{|l|}{24 Months } \\
\hline & OT $(n=162)$ & $\begin{array}{l}\text { Control } \\
(n=164)\end{array}$ & OT $(n=148)$ & $\begin{array}{l}\text { Control } \\
(n=142)\end{array}$ & OT $(n=140)$ & $\begin{array}{l}\text { Control } \\
(n=141)\end{array}$ & OT $(n=134)$ & $\begin{array}{l}\text { Control } \\
(n=124)\end{array}$ \\
\hline \multicolumn{9}{|l|}{ Joint protection } \\
\hline Use two hands & $57(93)$ & $55(90)$ & $66(97)$ & $57(81)$ & $66^{* *}(92)$ & $48(67)$ & $55(74)$ & $47(58)$ \\
\hline $\begin{array}{l}\text { Alter activities to reduce stress on } \\
\text { hands }\end{array}$ & $41(66)$ & $48(79)$ & $52^{* *}(77)$ & $38(54)$ & $51 * *(72)$ & $38(53)$ & $55^{* *}(74)$ & $40(50)$ \\
\hline $\begin{array}{l}\text { Take care/do activities more } \\
\text { slowly }\end{array}$ & $53(86)$ & $61(100)$ & $62(92)$ & $54(76)$ & $64(89)$ & $57(81)$ & $66(88)$ & $57(71)$ \\
\hline \multicolumn{9}{|l|}{ Exercise } \\
\hline Hand exercises & $12(20)$ & $9(15)$ & $65^{\star \star \star}(96)$ & $12(17)$ & $59^{* \star \star}(83)$ & $9(13)$ & $60^{* * *}(79)$ & $12(15)$ \\
\hline Arm exercises & $9(15)$ & $11(18)$ & $28^{\star \star *}(42)$ & $13(19)$ & $31^{* \star *}(44)$ & $11(15)$ & $31^{* * *}(41)$ & 14 (17) \\
\hline Fitness exercise & $29(47)$ & $21(35)$ & $39(57)$ & 37 (52) & $45(63)$ & $37(52)$ & 39 (52) & $39(48)$ \\
\hline \multicolumn{9}{|l|}{ Energy conservation } \\
\hline Regular rest & $50(81)$ & $57(93)$ & $52(77)$ & $59(84)$ & $59^{*}(83)$ & $46(52)$ & $48(64)$ & $56(70)$ \\
\hline Pace activity & $42(68)$ & 45 (73) & 49 (72) & $43(61)$ & $50(70)$ & $45(64)$ & $49(65)$ & $49(61)$ \\
\hline \multicolumn{9}{|l|}{ Treatment received: } \\
\hline Occupational therapy & $9(14)$ & $2(3)$ & $93^{* * *}(137)$ & $5(7)$ & $67^{* \star \star}(93)$ & $5(7)$ & $33^{*}(44)$ & $7(9)$ \\
\hline Physiotherapy & $15(25)$ & $15(25)$ & $14(20)$ & $18(26)$ & $12(16)$ & $9(13)$ & $10(13)$ & $6(7)$ \\
\hline Podiatry & $8(13)$ & $9(14)$ & 11 (16) & $13(18)$ & $16(22)$ & $14(20)$ & $14(19)$ & $17(21)$ \\
\hline
\end{tabular}

concordant worsening of functional ability in a control group enables the effects of secondary prevention to be identified. ${ }^{27}$

Thirdly, although the OT group significantly increased their use of some self management (for example, hand exercise and joint protection), the control group naturally adapted to using others (for example, pacing, doing activities more slowly, and fitness exercise) at similar levels to the OT group. It may be that insufficient people in the OT group used enough self management methods often enough to make a difference. A qualitative study conducted alongside this trial with 15 participants in the OT group offered some insight. ${ }^{35}$ Most found the therapists reassuring, empathetic, and conveyed that help was available in future. The main benefits were knowing more about RA and self management. Attitudinal changes occurred, such as greater acceptance of living with arthritis, less guilt about difficulties with daily activities and roles, and believing exercise and joint protection beneficial. However, a third of interviewees did not consider the programme appropriate: "I think we were all in the early stages of our arthritis, so we weren't really suffering particularly...I thought, we can cope at the moment," "It hasn't made a difference... I am not that bad yet," "It didn't really do anything for me. ... I don't think it helped as long as you are using your hands." "If you feel well it doesn't really occur to you does it? You get on with your normal life and it's fine."

Perceived threat from a disease strongly influences behavioural change. ${ }^{36}$ At the trial start a third of the OT group considered that they had mild disease, $75 \%$ that disease modifying drugs controlled their symptoms well/ moderately well, and $42 \%$ scored $<2$ on the AIMS2 PF scale (that is, few functional problems). Potentially, a third of the OT group did not consider self management relevant, as they were "not that bad yet". A third of people with early RA have little interest in learning about self management and are less likely to be contemplating health behaviour changes. ${ }^{37}$

Fourthly, OT might have been apparently ineffective owing to the delivery of the intervention. Adopting self management requires changes in habits and routines and time to develop skills. The OT programme developed pragmatically over years, rather than from a theoretical and evidence base. Methods typical of current UK practice in teaching self management were used-that is, short talks, demonstrations, and discussion. Joint protection education is effective for people with early RA "at risk" of hand problems, but how it is taught is critical. "Typical" AEPs do not significantly increase use of joint protection, but a behavioural approach does, and improvements in, pain, grip strength, early morning stiffness, and functional ability result. ${ }^{14}$

Systematic reviews of AEPs have shown that behavioural education is more effective in improving adherence and health status in RA than information programmes. ${ }^{38} 39$ The OT programme did not use behavioural approaches. Group behavioural education is more effective than individual education, as it provides greater opportunities for feedback, modelling, and mutual support, ${ }^{40}$ but again this was not used. However, whether behavioural education programmes are effective in early RA is unclear. Two studies have shown adherence improves but not health status in people at an average of 4.5 months $^{41}$ and $<3$ years ${ }^{42}$ after diagnosis, but the follow up periods were short (6 and 12 months), meaning any benefits might not yet have been detected.

This study suggests that rheumatology departments should think twice before providing early secondary preventive intervention to everyone with RA using current "typical" methods. Was it too early for some and less effective for others? The qualitative study highlighted the fact that the education and support from OT were deemed helpful by many, but a third found it "too early". Boutagh and Brady point out that people not yet contemplating change will not respond to traditional interventions or behavioural programmes. ${ }^{43}$ They require specific input first to increase their awareness of the importance of recommendations. Short group educational programmes about RA, drug treatment, and benefits of self management (for example, two hours), supported with information leaflets, help efficiently meet early educational needs. Motivational interviewing can be used by doctors and rheumatology nurses in clinic to emphasise the benefits of self management and explore attitudes to change. Timely identification of readiness to change enables relevant referral to behavioural AEPs. OT can meet individual needs as more functional, physical, and psychosocial problems develop.

This study concluded that OT teaching preventive self management methods improved adherence. Many found it reassuring and informative. It did not affect health status after two years, but this is relatively well preserved in the first five years of RA. OT may act preventively, but only a longer 


\begin{tabular}{|c|c|c|c|c|c|c|c|}
\hline & 0 Months & $\begin{array}{l}\text { Change scores at } \\
6 \text { months }\end{array}$ & $\begin{array}{l}6 \text { Months } \\
\text { (p) }\end{array}$ & $\begin{array}{l}\text { Change scores at } \\
12 \text { months }\end{array}$ & $\begin{array}{l}12 \text { Months } \\
\text { (p) }\end{array}$ & $\begin{array}{l}\text { Change scores at } \\
24 \text { months }\end{array}$ & 24 Months (p) \\
\hline \multicolumn{8}{|c|}{ Primary outcomes: } \\
\hline \multicolumn{8}{|c|}{ Pain VAS } \\
\hline OT & $\begin{array}{l}41.09 \\
\text { (36.79 to } 45.39)\end{array}$ & $\begin{array}{l}-4.46 \\
(-8.44 \text { to }-0.48)\end{array}$ & 0.37 & $\begin{array}{l}-1.42 \\
(-6.51 \text { to } 3.66)\end{array}$ & 0.85 & $\begin{array}{l}-0.94 \\
(-6.08 \text { to } 4.20)\end{array}$ & 0.75 \\
\hline Control & $\begin{array}{l}43.21 \\
\text { (38.55 to } 47.88)\end{array}$ & $\begin{array}{l}-1.54 \\
(-6.51 \text { to } 3.44)\end{array}$ & & $\begin{array}{l}-2.12 \\
(-7.26 \text { to } 3.03)\end{array}$ & & $\begin{array}{l}-2.15 \\
(-7.56 \text { to } 3.27)\end{array}$ & \\
\hline \multicolumn{8}{|c|}{$\begin{array}{l}\text { AIMS2: physical function } \\
\text { scale }\end{array}$} \\
\hline OT & $\begin{array}{l}2.71 \\
(2.40 \text { to } 3.02)\end{array}$ & $\begin{array}{l}-0.37 \\
(-0.56 \text { to }-0.17)\end{array}$ & 0.50 & $\begin{array}{l}-0.33 \\
(-0.53 \text { to }-0.13)\end{array}$ & 0.65 & $\begin{array}{l}-0.11 \\
(-0.44 \text { to } 0.23)\end{array}$ & 0.14 \\
\hline Control & $\begin{array}{l}2.87 \\
(2.54 \text { to } 3.21)\end{array}$ & $\begin{array}{l}-0.46 \\
(-0.65 \text { to }-0.27)\end{array}$ & & $\begin{array}{l}-0.40 \\
(-0.61 \text { to }-0.19)\end{array}$ & & $\begin{array}{l}-0.67 \\
(-1.02 \text { to }-0.32)\end{array}$ & \\
\hline \multicolumn{8}{|c|}{10.000 .019} \\
\hline OT & $\begin{array}{l}1.10 \\
(0.97 \text { to } 1.23)\end{array}$ & - & - & $\begin{array}{l}-0.11 \\
(-0.18 \text { to }-0.03)\end{array}$ & 0.39 & $\begin{array}{l}-0.16 \\
(-0.30 \text { to }-0.01)\end{array}$ & 0.37 \\
\hline Control & $\begin{array}{l}1.16 \\
(1.02 \text { to } 1.31)\end{array}$ & - & & $\begin{array}{l}-0.16 \\
(-0.25 \text { to }-0.07)\end{array}$ & & $\begin{array}{l}-0.19 \\
(-0.30 \text { to }-0.08)\end{array}$ & \\
\hline \multicolumn{8}{|c|}{ Total self efficacy scale } \\
\hline & $\begin{array}{l}61.59 \\
(59.04 \text { to } 65.01)\end{array}$ & $\begin{array}{l}4.62 \\
(2.21 \text { to } 7.04)\end{array}$ & 0.47 & $\begin{array}{l}4.58 \\
(2.13 \text { to } 7.03)\end{array}$ & 0.22 & $\begin{array}{l}3.41 \\
\text { (0.89 to } 5.93 \text { ) }\end{array}$ & 0.48 \\
\hline Control & $\begin{array}{l}60.88 \\
(57.75 \text { to } 64.02)\end{array}$ & $\begin{array}{l}3.41 \\
(1.12 \text { to } 5.71)\end{array}$ & & $\begin{array}{l}2.49 \\
(0.14 \text { to } 4.85)\end{array}$ & & $\begin{array}{l}4.88 \\
(2.30 \text { to } 7.45)\end{array}$ & \\
\hline \multicolumn{8}{|c|}{$\begin{array}{l}\text { Secondary outcomes: } \\
28 \text { Swollen joint count }\end{array}$} \\
\hline OT & $\begin{array}{l}7.81 \\
(6.70 \text { to } 8.93)\end{array}$ & $\begin{array}{l}-0.62 \\
(-1.70 \text { to } 0.46)\end{array}$ & 0.91 & $\begin{array}{l}-0.93 \\
(-2.13 \text { to } 0.28)\end{array}$ & 0.94 & $\begin{array}{l}-1.25 \\
(-2.58 \text { to } 0.08)\end{array}$ & 0.59 \\
\hline Control & $\begin{array}{l}7.99 \\
(6.83 \text { to } 9.14)\end{array}$ & $\begin{array}{l}-0.70 \\
(-1.74 \text { to } 0.34)\end{array}$ & & $\begin{array}{l}-0.85 \\
(-2.14 \text { to } 0.44)\end{array}$ & & $\begin{array}{l}-1.73 \\
(-2.92 \text { to }-0.54)\end{array}$ & \\
\hline \multicolumn{8}{|c|}{28 Tender joint count } \\
\hline & $\begin{array}{l}9.62 \\
(8.08 \text { to } 11.15)\end{array}$ & $\begin{array}{l}-1.72 \\
(-2.92 \text { to }-0.51)\end{array}$ & 0.61 & $\begin{array}{l}-1.69 \\
(-2.97 \text { to }-0.41)\end{array}$ & 0.79 & $\begin{array}{l}-1.64 \\
(-3.19 \text { to } 0.08)\end{array}$ & 0.66 \\
\hline Control & $\begin{array}{l}10.25 \\
\text { (8.73 to } 11.77 \text { ) }\end{array}$ & $\begin{array}{l}-1.32 \\
(-2.28 \text { to }-0.36)\end{array}$ & & $\begin{array}{l}-1.95 \\
(-3.26 \text { to }-0.64)\end{array}$ & & $\begin{array}{l}-2.10 \\
(-3.37 \text { to }-0.83)\end{array}$ & \\
\hline \multicolumn{8}{|c|}{ Early morning stiffness (min) } \\
\hline OT & $\begin{array}{l}70.22 \\
(50.95 \text { to } 89.48)\end{array}$ & $\begin{array}{l}+5.51 \\
(-22.56 \text { to } 33.57)\end{array}$ & 0.41 & $\begin{array}{l}-6.77 \\
(-31.35 \text { to } 17.79)\end{array}$ & 0.91 & $\begin{array}{l}-17.31 \\
(-41.48 \text { to } 6.85)\end{array}$ & 0.94 \\
\hline Control & $\begin{array}{l}62.74 \\
(44.56 \text { to } 80.93)\end{array}$ & $\begin{array}{l}-9.20 \\
(-30.14 \text { to } 11.74)\end{array}$ & & $\begin{array}{l}-8.69 \\
(-32.17 \text { to } 14.79)\end{array}$ & & $\begin{array}{l}-16.06 \\
(-35.03 \text { to } 2.91)\end{array}$ & \\
\hline \multicolumn{8}{|c|}{ Power grip (kg) } \\
\hline OT & $\begin{array}{l}14.86 \\
(13.52 \text { to } 16.18)\end{array}$ & $\begin{array}{l}1.57 \\
(0.84 \text { to } 2.30)\end{array}$ & 0.84 & $\begin{array}{l}2.31 \\
\text { (1.44 to } 3.19)\end{array}$ & 0.75 & $\begin{array}{l}1.77 \\
(0.67 \text { to } 2.88)\end{array}$ & 0.41 \\
\hline Control & $\begin{array}{l}14.81 \\
(13.26 \text { to } 16.36)\end{array}$ & $\begin{array}{l}1.70 \\
(0.74 \text { to } 2.66)\end{array}$ & & $\begin{array}{l}2.09 \\
(1.03 \text { to } 3.16)\end{array}$ & & $\begin{array}{l}2.44 \\
(1.29 \text { to } 3.57)\end{array}$ & \\
\hline \multicolumn{8}{|c|}{ Jebsen test (s) } \\
\hline OT & $\begin{array}{l}37.74 \\
(36.17 \text { to } 39.32)\end{array}$ & $\begin{array}{l}-0.29 \\
(-1.50 \text { to } 0.91)\end{array}$ & 0.36 & $\begin{array}{l}-0.94 \\
(-2.37 \text { to } 0.48)\end{array}$ & 0.29 & $\begin{array}{l}-0.03 \\
(-1.43 \text { to } 1.37)\end{array}$ & 0.22 \\
\hline Control & $\begin{array}{l}39.33 \\
(35.60 \text { to } 39.30)\end{array}$ & $\begin{array}{l}-1.21 \\
(-2.76 \text { to } 0.35)\end{array}$ & & $\begin{array}{l}-2.21 \\
(-4.00 \text { to }-0.41)\end{array}$ & & $\begin{array}{l}-1.38 \\
(-3.02 \text { to } 0.28)\end{array}$ & \\
\hline \multicolumn{8}{|c|}{$\begin{array}{l}\text { Arthritis Impact Measurement Scale version 2: } \\
\text { Pain/other symptoms scale }\end{array}$} \\
\hline OT & $\begin{array}{l}5.21 \\
(4.83 \text { to } 5.59)\end{array}$ & $\begin{array}{l}-0.80 \\
(-1.09 \text { to }-0.52)\end{array}$ & 0.76 & $\begin{array}{l}-0.82 \\
(-1.15 \text { to }-0.49)\end{array}$ & 0.76 & $\begin{array}{l}-0.55 \\
(-1.15 \text { to }-0.06)\end{array}$ & 0.14 \\
\hline Control & $\begin{array}{l}5.69 \\
(5.31 \text { to } 6.07)\end{array}$ & $\begin{array}{l}-0.73 \\
(-1.09 \text { to }-0.37)\end{array}$ & & $\begin{array}{l}-0.74 \\
(-1.14 \text { to }-0.34)\end{array}$ & & $\begin{array}{l}-1.34 \\
(-1.99 \text { to }-0.68)\end{array}$ & \\
\hline \multicolumn{8}{|l|}{ Affect scale } \\
\hline OT & $\begin{array}{l}4.17 \\
(3.87 \text { to } 4.47)\end{array}$ & $\begin{array}{l}-0.30 \\
(-0.49 \text { to }-0.12)\end{array}$ & 0.36 & $\begin{array}{l}-0.44 \\
(-0.63 \text { to }-0.25)\end{array}$ & 0.15 & $\begin{array}{l}0.16 \\
(-0.18 \text { to } 0.49)\end{array}$ & 0.71 \\
\hline Control & $\begin{array}{l}4.10 \\
(3.80 \text { to } 4.40)\end{array}$ & $\begin{array}{l}-0.18 \\
(-0.36 \text { to }-0.11)\end{array}$ & & $\begin{array}{l}-0.24 \\
(-0.44 \text { to }-0.04)\end{array}$ & & $\begin{array}{l}-0.22 \\
(-0.57 \text { to } 0.13)\end{array}$ & \\
\hline \multicolumn{8}{|c|}{ Work ability* } \\
\hline OT & $\begin{array}{l}3.08 \\
(2.41 \text { to } 3.77)\end{array}$ & $\begin{array}{l}-0.91 \\
(-1.63 \text { to }-0.20)\end{array}$ & 0.91 & $\begin{array}{l}-0.73 \\
(-1.44 \text { to }-0.01)\end{array}$ & 0.77 & $\begin{array}{l}-0.36 \\
(-1.08 \text { to } 0.34)\end{array}$ & \\
\hline Control & $\begin{array}{l}3.91 \\
(1.61 \text { to } 2.73)\end{array}$ & $\begin{array}{l}-1.03 \\
(-1.68 \text { to }-0.37)\end{array}$ & & $\begin{array}{l}-0.92 \\
(-1.58 \text { to }-0.25)\end{array}$ & & $\begin{array}{l}-0.92 \\
(-1.73 \text { to }-0.12)\end{array}$ & 0.30 \\
\hline \multicolumn{8}{|c|}{ Satisfaction with health } \\
\hline & $\begin{array}{l}4.44 \\
(4.08 \text { to } 4.79)\end{array}$ & $\begin{array}{l}0.61 \\
(-0.9 \text { to }-0.32)\end{array}$ & 0.81 & $\begin{array}{l}-0.75 \\
(-1.06 \text { to }-0.45)\end{array}$ & 0.47 & $\begin{array}{l}-0.61 \\
(-1.13 \text { to }-0.08)\end{array}$ & 0.56 \\
\hline Control & $\begin{array}{l}4.42 \\
(4.05 \text { to } 4.79)\end{array}$ & $\begin{array}{l}-0.66 \\
(-0.95 \text { to }-0.37)\end{array}$ & & $\begin{array}{l}-0.59 \\
(-0.92 \text { to }-0.26)\end{array}$ & & $\begin{array}{l}-1.32 \\
(-1.97 \text { to }-0.68)\end{array}$ & \\
\hline \multicolumn{8}{|c|}{$\begin{array}{l}\text { Rheumatoid Attitudes Index } \\
\text { Helplessness }\end{array}$} \\
\hline OT & $\begin{array}{l}17.02 \\
(16.21 \text { to } 17.84)\end{array}$ & $\begin{array}{l}-1.32 \\
(-2.05 \text { to }-0.59)\end{array}$ & 0.51 & $\begin{array}{l}-1.39 \\
(-2.25 \text { to }-0.55)\end{array}$ & 0.05 & $\begin{array}{l}-1.18 \\
(-2.04 \text { to }-0.33)\end{array}$ & 0.29 \\
\hline Control & $\begin{array}{l}16.41 \\
(15.55 \text { to } 17.27)\end{array}$ & $\begin{array}{l}-0.97 \\
(-1.71 \text { to }-0.24)\end{array}$ & & $\begin{array}{l}-0.30 \\
(-0.99 \text { to } 0.39)\end{array}$ & & $\begin{array}{l}-0.49 \\
(-1.40 \text { to } 0.41)\end{array}$ & \\
\hline
\end{tabular}


Table 3 Continued

\begin{tabular}{|c|c|c|c|c|c|c|c|}
\hline & 0 Months & $\begin{array}{l}\text { Change scores at } \\
6 \text { months }\end{array}$ & $\begin{array}{l}6 \text { Months } \\
\text { (p) }\end{array}$ & $\begin{array}{l}\text { Change scores at } \\
12 \text { months }\end{array}$ & $\begin{array}{l}12 \text { Months } \\
\text { (p) }\end{array}$ & $\begin{array}{l}\text { Change scores at } \\
24 \text { months }\end{array}$ & 24 Months (p) \\
\hline \multicolumn{8}{|c|}{ Perceived control } \\
\hline OT & $\begin{array}{l}18.02 \\
(17.19 \text { to } 18.86)\end{array}$ & $\begin{array}{l}-1.08 \\
(-1.98 \text { to }-0.17)\end{array}$ & 0.96 & $\begin{array}{l}-1.25 \\
(-2.10 \text { to }-0.39)\end{array}$ & 0.17 & $\begin{array}{l}-1.63 \\
(-2.53 \text { to }-0.73)\end{array}$ & 0.93 \\
\hline \multirow[t]{2}{*}{ Control } & 18.19 & -1.05 & & -0.44 & & -1.58 & \\
\hline & (17.41 to 18.98$)$ & $(-1.83$ to -0.27$)$ & & $(-1.23$ to 0.35$)$ & & $(-2.45$ to -0.70$)$ & \\
\hline \multicolumn{8}{|c|}{$\begin{array}{l}\text { No of doctor visits for } \\
\text { arthritis }\end{array}$} \\
\hline \multirow[t]{2}{*}{ OT } & 3.10 & -0.48 & 0.70 & -0.88 & 0.42 & -1.07 & 0.10 \\
\hline & (2.79 to 3.41$)$ & $(-0.83$ to -0.11$)$ & & $(-1.20$ to -0.56$)$ & & $(-1.40$ to -0.74$)$ & \\
\hline \multirow[t]{2}{*}{ Control } & 3.00 & -0.58 & & 0.63 & & -0.53 & \\
\hline & ( 2.63 to 3.37 ) & $(-0.95$ to -0.21$)$ & & $(-1.15$ to -0.12$)$ & & $(-1.09$ to 0.03$)$ & \\
\hline
\end{tabular}

VAS, visual analogue scale.

* $n=65$ OT; $n=64$ control.

term follow up will answer this. The third of patients with more functional problems were provided with relevant ADL training, assistive devices, and environmental modifications, and clinical guidelines emphasise that those with early functional difficulties should receive OT. ${ }^{44}$ Whether this helps to preserve function in this subset also needs investigation through longer term follow up. Further clinical trials are needed to evaluate OT programmes, with subsets of patients identified early as being "at risk". For example, those "at risk" of greater functional disability (such as, HAQ scores $>1$, with greater depression and poorer socioeconomic status) may benefit from comprehensive OT; of hand function problems (such as, high hand pain and high hand disability scores) from a focused behavioural joint protection and hand exercise programme; and of work disability from work assessment. Trials of the effectiveness of motivational interviewing and behavioural self management programmes in early RA in facilitating adherence and health status are needed. Long term follow up studies (5-10 years) are essential to evaluate whether these interventions can truly be preventive, over and above the effects of drug treatment.

OT is a complex intervention. This trial evaluated a programme developed pragmatically, which was reflective of UK practice. Future studies need to use the Medical Research Council's framework for the development and evaluation of randomised controlled trials for complex interventions, using a sound theoretical and evidence base. ${ }^{45}$ Research is needed to determine the best choices of OT interventions for whom and when in this group of patients with early disease.

\section{ACKNOWLEDGEMENTS}

This trial was funded by NHS R\&D Programme for people with physical and complex disabilities; North Thames Regional Health Authority R\&D Response Funding programme, and the Arthritis Research Campaign.

Particular thanks are due to the following: rheumatologists and occupational therapists for their hard work and support for this trial: Dr Wajed, Dr Kola, Marion Ferguson, Pru Biddle (head OTs), Sue Morris (senior OT), (St Albans City and Hemel Hempstead General Hospitals); Dr Sinclair, Dr Grayson (North Middlesex Hospital); Dr Pandit and Anna Pratt (Watford and Mount Vernon Hospitals); Dr Sturge, Dr Rosenberg, Dr Smith, and Ruth Cyrus (Barnet and Egdware General Hospitals); Dr Griffin, Dr Yuksel, Dr Mulcahy, Debbie Lindley, and Tanya Pugh (Chase Farm Hospital); Dr Axon and Alison Lilleywhite (Queen Elizabeth II Hospital, Welwyn); Dr Currey and Jill Deighton (Queen Alexandra Hospital, Harlow); Dr Keat (Northwick Park Hospital); Dr Room, Dr Naughton and Sally Davis (Ealing Hospital).

Statistical and design advice was provided initially by Dr A Frater, public health specialist, Hertfordshire Health Authority and Professor S Gallivan, Clinical Operational Research Unit, University College London, and latterly from Trent Institute for Health Services Research, University of Nottingham.
Many thanks also to Cathy Mayes and staff at RAG (St Albans), Jessica Jackson, Sharon Morris and Jo Harrison (Rheumatology Research Unit, Derbyshire Royal Infirmary) for help with data management.

\section{Authors' affiliations}

A Hammond, Rheumatology, Derbyshire Royal Infirmary, London Road, Derby DE1 2QY, UK

A Young, R Kidao, St Albans City Hospital, Waverley Road, St Albans, Herffordshire AL1 5PN, UK

\section{REFERENCES}

1 Sanford M, Silverman SL, Wolfe T. Rheumatoid arthritis. In: Melvin JL, Ferrell KM, eds. Adult rheumatic diseases. Vol 2. Maryland, Bethesda: The American Occupational Therapy Association, 2000:161-204. (Rheumatologic rehabilitation series.)

2 Arthritis Health Professionals Association. Briefing paper: the role of occupational therapy in the management of patients with rheumatic diseases. 1314 Spring Street, NW Atlanta, Georgia 30309, USA, AHPA, 1992.

3 Helewa A, Goldsmith C, Lee P, Bombardier C, Hanes B, Smythe H A, et al. Effects of occupational therapy home service on patients with rheumatoid arthritis. Lancet 1991;337:1453-6.

4 Brighton S, Lubbe J, van der Merwe CA. The effect of a long-term exercise programme on the rheumatoid hand. Br J Rheumatol 1993;32:392-5.

5 Buljina Al, Taljanovic MS, Avdic DM, Hunter TB. Physical and exercise therapy for treatment of the rheumatoid hand. Arthritis Rheum 2001;45:392-7.

6 Dellhag B, Wollersjo I, Bjelle A. Effect of active hand exercise and wax bath treatment in rheumatoid arthritis patients. Arthritis Care Res 1992;5:87-92.

7 Hoenig H, Groff G, Pratt K, Goldberg E, Franck W. A randomized controlled trial of home exercise on the rheumatoid hand. J Rheumatol 1993;20:785-9.

8 Kjeken I, Moller G, Kvien T. Use of commercially produced elastic wrist orthoses in chronic arthritis: a controlled study. Arthritis Care Res 1995;8:108-13.

9 Nordenskiold U. Elastic wrist orthoses: a reduction in pain and increase in grip force for women with rheumatoid arthritis. Arthritis Care Res 1990;3:158-62.

10 Stern EB, Ytterberg SR, Krug HE, Mullin GT, Mahowald ML. Immediate and short term effects of three commercial wrist extensor orthoses on grip strength and function in patients with rheumatoid arthritis. Arthritis Care Res 1996;9:42-50.

11 Nordenskield U. Evaluation of assistive devices after a course of joint protection. Int J Technol Assess Health Care 1994;10:293-304.

12 Nordenskiold U, Grimby G, Dahlin-lvanoff S. Questionnaire to evaluate the effects of assistive devices and altered working methods in women with rheumatoid arthritis. Clin Rheumatol 1998;17:6-16.

13 Li CWP, Yung PMB, Chu EMY, Lau CS, Leung BPK The efficacy of a combined joint protection and behavioural management programme on the functional status of patients with rheumatoid arthritis. Arthritis Care Res 2001;45:S9 (abstr 673).

14 Hammond A, Freeman KE. One year outcomes of a randomized controlled trial of an educational-behavioural joint protection programme for people with rheumatoid arthritis. Rheumatology (Oxford) 2001;40:1044-51.

15 Steultiens EM, Dekker J, Bouter LM, van Schaardenburg D, van Kuyk MH, Van der Ende $\mathrm{CH}$. Occupational therapy for rheumatoid arthritis: a systematic review. Arthritis Rheum 2002;47:672-85.

16 Altman DG. Practical statistics for medical research. London: Chapman \& Hall, 1991:87-8

17 Boers M, Tugwell P. The validity of pooled outcome measures (indices) in rheumatoid arthritis clinical trials. J Rheumatol 1993;20:568-74.

18 van der Heide A, Jacobs JWG, van Albada-Kuipers GA, Kraaimaat F W, Geenen R, Bijlsma JWJ. Physical disability and psychological well being in recent onset rheumatoid arthritis. J Rheumatol 1994;21:28-32. 
19 Kirwan JR, Reeback JS. Stanford Health Assessment Questionnaire modified to assess disability in British patients with rheumatoid arthritis. Br J Rheumatol 1986;25:206-9.

20 Meenan RF, Mason JH, Anderson JJ, Guccione AA, Kazis LA. AIMS2: the content and properties of a revised and expanded arthritis impact measurement scales health status questionnaire. Arthritis Rheum 1992;35: 1-10.

21 Scott DL, van Riel PL, van der Heijde D, Benke AS. Assessing disease activity in rheumatoid arthritis. The EULAR handbook of standard methods. Switzerland: EULAR, 1993

22 Steinbrocker $O$, Traeger C, Batterman RC. Therapeutic criteria in rheumatoid arthritis. J AMA 1949;14:659-62.

23 Gilbertson L, Barber-Lomax S. Power and pinch grip strength recorded using the hand-held JAMAR dynamometer and B+L hydraulic pinch gauge: British normative data for adults. Br J Occup Therapy 1994;57:483-8.

24 Jebsen R H, Taylor N, Trieschmann RB, Trotter MJ, Howard LA. An objective and standardised test of hand function. Archiv Phys Med Rehabil 1969:50:311-19.

25 Barlow JH, Williams B, Wright CC. The reliability and validity of the arthritis self-efficacy scale in a UK context. Psychology, Health and Medicine 1997;2:3-17

26 Callahan LF, Brooks RH, Pincus T. Further analysis of learned helplessness in rheumatoid arthritis using a "Rheumatology Attitudes Index." J Rheumatol 1988:15:418-26.

27 Stucki G. Understanding disability. Ann Rheum Dis 2003;62:289-90.

28 Eberhardt KB, Rydgren LC, Pettersson H, Wollheim FA. Early rheumatoid arthritis - onset, course and outcome over two years. Rheumatol Int 1990; 10:135-42.

29 Eberhardt K, Fex E. Functional Impairment and disability in early rheumatoid arthritis-development over 5 years. J Rheumatol 1995;22:1037-42.

30 Harrison B, Symmons D. Early inflammatory polyarthritis: results from the Norfolk arthritis register with a review of the literature. II. Outcome at three years. Rheumatology (Oxford) 2000;39:939-49.

31 Uhlig T, Smedstad LM, Vaglum P, Moum T, Gerard N, Kvien TK. The course of rheumatoid arthritis and predictors of psychological, physical and radiographic outcome after 5 years follow-up. Rheumatology (Oxford) 2000;39:732-41.

32 Young A, Dixey J, Cox N, Davies P, Devlin J, Emery P, et al. How does functional disability in early rheumatoid arthritis (RA) affect patients and their lives? Results of 5 years of follow-up in 732 patients from the Early RA Study (ERAS). Rheumatology(Oxford) 2000;39:603-11.
33 Carr AJ. Margaret Holroyd prize essay. A patient-centred approach to evaluation and treatment in rheumatoid arthritis: the development of a clinical tool to measure patient-perceived handicap. Br J Rheumatol 1996:35:921-32.

34 McConnell S, Beaton DE, Bombardier C. The DASH outcome measure user's manual. Toronto, Ontario, Canada: Institute of Work and Health, 1999.

35 Kidao R. The psychosocial impact of occupational threrapy on the experience of people with early rheumatoid arthritis. University of Derby, 2001 (M.Phil thesis.)

36 Janz NK, Becker MH. The health belief model: a decade later. Health Educ Q 1984;11:1-47.

37 Hammond A, Badcock $\sqcup$. Improving education about arthritis: identifying the educational needs of people with chronic arthritis. Rheumatology (Oxford) 2002;41(suppl 1):84.

38 Superio-Cabuslay E, Ward MM, Lorig K. Patient education interventions in osteoarthritis and rheumatoid arthritis: a meta-analytic comparison with nonsteroidal anti-inflammatory drug treatment. Arthritis Care Res 1996;9:292-301.

39 Riemsma RP, Kirwan JR, Taal E, Rasker JJ. Patient education for adults with rheumatoid arthritis [systematic review]. Cochrane Musculoskeletal Group Cochrane Database of Systematic Reviews, issue 4, 2002.

40 Riemsma RP, Taal E, Brus HLM, Rasker JJ, Wiegman O. Coordinated individual education with an arthritis passport for patients with rheumatoid arthritis. Arthritis Care Res 1997;10:238-49.

41 Freeman KE, Hammond A, Lincoln NB. Use of cognitive-behavioural arthritis education programmes in newly diagnosed rheumatoid arthritis. Clin Rehabil 2002; 16:828-36

42 Brus HLM, van der Laar MAFJ, Taal E, Rasker JH. Effects of patient education on compliance with basic treatment regimens and health in recent onset active rheumatoid arthritis. Ann Rheum Dis 1998;57:146-51.

43 Boutagh ML, Brady TJ. Patient education for self management. In: Melvin JL, Ferrell KM, eds. Adult rheumatic diseases. Vol 2. Maryland, Bethesda: The American Occupational Therapy Association, 1998. (Rheumatologic rehabilitation series.)

44 Scottish Intercollegiate Guidelines Network. Management of early rheumatoid arthritis. Royal College of Physicians of Edinburgh, 2000 (www.sign.ac.uk, accessed 7 March 2003).

45 Medical Research Council. A framework for the development and evaluation of RCTs for complex interventions to improve health. MRC, 2000. (www.mrc.ac.uk/prn/pdf-mrc_cpr.pdf, accessed 7 March 2003).

Get published within days of acceptance with ARD

We are delighted to announce that the Annals of the Rheumatic Diseases is launching a "publish ahead of print" programme from February 2004. Selected papers will be fast tracked and published online months before they appear in the print journal.

Papers of major significance to the international rheumatology community will be published within days of acceptance. The published article will be the raw accepted manuscript; edited and typeset versions will also be published as soon as they are available.

In addition to being available on ARD Online, the publish ahead of print articles will be searchable through PubMed/Medline-establishing primacy for your work. They will be linked from the ARD Online home page.

$A R D$ 's publish ahead of print programme is unique among the major rheumatology journals - to take advantage of this service submit your papers to Annals of the Rheumatic Diseases using our online submission and review system Bench>Press (http://submit-ard. bmijournals.com). For further information contact ARD@bmigroup.com. 